\author{
Dominika NarożNa, Katarzyna Ewa NowaK
}

Uniwersytet im. Adama Mickiewicza w Poznaniu

\title{
Własność intelektualna w uczelni publicznej (część 2)1. Casus Uniwersytetu im. Adama Mickiewicza w Poznaniu
}

Streszczenie: Własność intelektualna i jej ochrona jest zagadnieniem aktualnym i ustawicznie fluktuującym. Wiele na ten temat napisano, ale jeszcze niejedno zostanie na ten temat wyartykułowane, nie tylko z uwagi na zmiany w prawodawstwie, lecz także ze względu na wiele szczegółowych aspektów tego zagadnienia, które wymagają zastanowienia lub rozważenia. Autorki niniejszego artykułu mają zamiar skupić się na zagadnieniu własności intelektualnej w uczelniach publicznych. Temat ten staje się tym bardziej aktualny, że coraz częściej spotyka się hasła i inicjatywy mające na celu pogłębienie współpracy pomiędzy nauką i przemysłem, co nieodzownie łączy się z kwestiami praw, które staną się przedmiotem rozważań niniejszej publikacji.

Słowa kluczowe: ochrona własności intelektualnej, utwór, podmioty prawa autorskiego

$\mathbf{U}$ stawa z dnia 27 lipca 2005 r. Prawo o szkolnictwie wyższym² (zwana dalej p.s.w.), w swym pierwotnym brzmieniu wskazywała, że „W celu lepszego wykorzystania potencjału intelektualnego i technicznego uczelni oraz transferu wyników prac naukowych do gospodarki, uczelnie mogą prowadzić akademickie inkubatory przedsiębiorczości oraz centra transferu technologii" (art. 86 ust. 1 p.s.w.). W dalszych ustępach tego artykułu ustawodawca wskazał formy oraz cele, dla których można te jednostki utworzyć. Jednak żadne przepisy p.s.w. nie odnosiły się bezpośrednio do własności intelektualnej powstałej w uczelni. Zastosowanie w tym zakresie miały przede wszystkim dwie ustawy, ustawa z dnia 4 lu-

${ }^{1}$ Artykuł ten jest kontynuacją, a zarazem uzupełnieniem wcześniejszej publikacji napisanej przez jedną z autorek do niniejszego czasopisma. Zob. D. Narożna, Własność intelektualna w kontekście funkcjonowania uczelni wyższej w Polsce (część 1), „Środkowoeuropejskie Studia Polityczne” 2012, nr 4, s. 273-285.

${ }^{2}$ Dz. U. 2012, poz. 572, j.t. ze zm. 
tego 1994 r. o prawie autorskim i prawach pokrewnych ${ }^{3}$, (zwana dalej u.p.a.p.p.) oraz ustawa z dnia 30 czerwca 2000 r. Prawo własności przemystowej ${ }^{4}$ (zwana dalej p.w.p).

Z dniem 1 października 2011 r. weszły w życie zmiany do ustawy Prawo o szkolnictwie wyższym, wprowadzające do tego aktu normatywnego nowe przepisy, zgodnie z którymi uczelnie otrzymały podstawę prawną do utworzenia spółki kapitałowej (spółki z ograniczoną odpowiedzialnością lub spółki akcyjnej), której celem miała być komercjalizacja wyników badań naukowych i prac rozwojowych (zwanej „spółką celową") ${ }^{5}$. Nowe przepisy (wprowadzone przywołaną w zdaniu poprzednim nowelizacją) dawały także podstawę dla uchwalenia przez Senat uczelni regulaminu zarządzania prawami autorskimi i prawami pokrewnymi oraz prawami własności przemysłowej, a także zasad komercjalizacji wyników badań naukowych i prac rozwojowych. Nowelizacja ta nie wprowadzała jednak żadnych zmian odnoszących się bezpośrednio do własności intelektualnej powstałej $\mathrm{w}$ uczelni, tak więc $\mathrm{w}$ dalszym ciagu zastosowanie $\mathrm{w}$ tym zakresie miały przede wszystkim przepisy ustawy o prawie autorskim i prawach pokrewnych oraz ustawy Prawo własności przemysłowej.

Ustawą z dnia 11 lipca 2014 r. o zmianie ustawy - Prawo o szkolnictwie wyższym oraz niektórych innych ustaw ${ }^{6}$, która weszła w życie z dniem 1 października 2014 r., zmieniono w sposób zasadniczy kwestie dotyczące zasad komercjalizacji własności intelektualnej powstałej w uczelniach publicznych. Nowelizacja ta, między innymi, rozróżniła komercjalizację bezpośrednią i pośrednią oraz wprowadziła ogólne mechanizmy prowadzenia tych dwóch form komercjalizacji. Przede wszystkim jednak nowelizacja wprowadziła nowe, odmienne od dotychczasowych, zasady związane z prawami własności intelektualnej, a w zasadzie prawami własności przemysłowej do wyników badań naukowych lub prac rozwojowych oraz do know-how związanego z tymi wynikami, powstałymi w ramach wykonywania przez pracownika uczelni publicznej obowiązków ze stosunku pracy. Bowiem od wejścia w życie tej nowelizacji, jedynie „W sprawach nieuregulowanych ustawą stosuje się przepisy ustawy

${ }^{3}$ Dz. U. 2006, Nr 90, poz. 631 j.t. ze zm.

${ }^{4}$ Dz. U. 2013, poz. 1410 j.t. ze zm.

${ }^{5}$ Zob. Art. 1 pkt 66 ustawy z dnia 18 marca 2011 r. o zmianie ustawy - Prawo o szkolnictwie wyższym, ustawy o stopniach naukowych i tytule naukowym oraz o stopniach i tytule w zakresie sztuki oraz o zmianie niektórych innych ustaw, Dz. U. 2011, Nr 84, poz. 455 ze zm.

${ }^{6}$ Dz. U. 2014, poz. 1198, ze zm. 
z dnia 4 lutego 1994 r. o prawie autorskim i prawach pokrewnych [...], ustawy z dnia 30 czerwca 2000 r. - Prawo własności przemysłowej [...] oraz ustawy z dnia 26 czerwca 2003 r. o ochronie prawnej odmian roślin (Dz. U. Nr 137, poz. 1300, z późn. zm.)"’.

\section{Prawo autorskie}

Ustawa Prawo o szkolnictwie wyższym, w obecnym brzmieniu, reguluje przede wszystkim prawa do wyników badań naukowych będących wynalazkiem, wzorem użytkowym, wzorem przemysłowym lub topografią układu scalonego, wyhodowaną albo odkrytą i wyprowadzoną odmianą rośliny, do prac rozwojowych oraz do know-how związanego z tymi wynikami, powstałych w ramach wykonywania przez pracownika uczelni publicznej obowiązków ze stosunku pracy. Przepisy te nie odnoszą się bezpośrednio do praw autorskich. Zatem zgodnie $\mathrm{z}$ art. 86 i p.s.w. w tym zakresie zastosowanie będą miały przepisy ustawy z dnia 4 lutego $1994 \mathrm{r}$. o prawie autorskim i prawach pokrewnych.

Zagadnienia związane $\mathrm{z}$ prawami autorskimi w uczelni publicznej można i należy rozpatrywać w kilu płaszczyznach. W pierwszej kolejności należy zauważyć, że o prawach autorskich w uczelni publicznej mówimy nie tylko w kontekście pracowników, ale także w kontekście studentów, doktorantów, czy uczestników innych form kształcenia.

Zgodnie $\mathrm{z}$ art. 15a u.p.a.p.p. „Uczelni w rozumieniu przepisów o szkolnictwie wyższym przysługuje pierwszeństwo w opublikowaniu pracy dyplomowej studenta.[...]". Studentem uczelni jest osoba kształcąca się na studiach wyższych, czyli studiach pierwszego stopnia (licencjackich), studiach drugiego stopnia (magisterskich) lub jednolitych studiach magisterskich, niezależnie od formy prowadzenia tych studiów (stacjonarnych albo niestacjonarnych). W odwołaniu do definicji zawartych w ustawie Prawo o szkolnictwie wyższym, studentami nie są doktoranci, będący uczestnikami studiów doktoranckich, słuchacze będący uczestnikami studiów podyplomowych, czy osoby uczestniczące w innych formach kształcenia takich jak kursy czy szkolenia. Tym samym przywołany przepis nie ma zastosowania m.in. do rozpraw doktorskich, czy też prac przygotowanych w ramach studiów podyplomowych czy innych, wyżej wymienionych form kształcenia. Dodatkowo należy zwrócić uwagę, że

\footnotetext{
7 Zob. Art. 86 i p.s.w.
} 
przywołany przepis mówi o pracach dyplomowych, a nie o wszystkich pracach przygotowywanych przez studenta w ramach odbywania studiów. Pracą dyplomową zgodnie z art. 167 a ust. 2 u.p.s.w. jest, ,samodzielne opracowanie określonego zagadnienia naukowego lub artystycznego lub dokonanie artystyczne prezentujące ogólną wiedzę i umiejętności studenta związane $\mathrm{z}$ danym kierunkiem studiów, poziomem i profilem kształcenia oraz umiejętności samodzielnego analizowania i wnioskowania". Wobec powyższego, normą zawartą w art. 15a u.p.a.p.p. nie są objęte prace zaliczeniowe, semestralne, czy też inne prace przygotowywane prze studentów w toku studiów, a mające charakter utworu. Omawianą normą prawną są zatem objęte jedynie rozprawy przygotowywane na koniec studiów (prace licencjackie, prace inżynierskie, czy prace magisterskie).

Prawo pierwszeństwa publikacji pracy dyplomowej jest ograniczone czasowo - ,[...] Jeżeli uczelnia nie opublikowała pracy dyplomowej w ciagu 6 miesięcy od jej obrony, student, który ją przygotował, może ją opublikować, chyba że praca dyplomowa jest częścią utworu zbiorowego"s. Co więcej, należy pamiętać, że na opublikowanie pracy dyplomowej uczelnia musi uzyskać wyraźną zgodę studenta. Gdy takowej nie ma, nie można w żadnym razie domniemywać jej z brzmienia omawianego przepisu. Co prawda powyższy przepis nie odnosi się w jakikolwiek sposób do kwestii związanych z wynagrodzeniem, należy jednak przyjąć, w oparciu o inne przepisy tejże ustawy, że studentowi jako autorowi przysługuje wynagrodzenie ${ }^{9}$. Stanowisko takie znajduje potwierdzenie między innymi w wyroku Sądu Okręgowego w Warszawie, zgodnie z którym uznano za niedozwolone postanowienie o następującym brzmieniu: „Student przenosi na Uczelnię autorskie prawa majątkowe do swojej pracy dyplomowej (licencjackiej, inżynierskiej lub magisterskiej) przygotowanej w ramach studiów realizowanych w SWSPiZ. Przeniesienie praw autorskich następuje nieodpłatnie na wszystkich polach eksploatacji, określonych w art. 50 ustawy z dnia 4 lutego 1994 r. o prawie autorskim i prawach pokrewnych"10.

Ustawa o prawie autorskim i prawach pokrewnych, w odniesieniu do studentów, reguluje jedynie prawo pierwszeństwa uczelni do opublikowania pracy dyplomowej, nie reguluje natomiast w sposób szczególny,

${ }^{8}$ Zob. Art. 15a u.p.a.p.p.

9 Prawo autorskie i prawa pokrewne. Komentarz Lex, red. D. Flisak, Warszawa 2015, s. 211-212.

${ }^{10}$ Wyrok Sądu Ochrony Konkurencji i Konsumentów z dnia 6 kwietnia 2006 r. wydany w sprawie o sygn. akt XVII AmC 48/05, niepubl. 
czy też odmienny, kwestii związanych z innymi prawami, w tym w szczególności z majątkowymi prawami do utworów (zarówno będących pracami dyplomowymi, jak również innymi pracami przygotowanymi przez studentów w toku studiów). Zatem w tym zakresie zastosowanie będą miały ogólne przepisy ustawy. W konsekwencji, wszelkie majątkowe prawa autorskie do utworów stworzonych przez studentów zarówno w ramach, jak i w związku z odbywaniem studiów - z jedynym wyjątkiem $\mathrm{w}$ postaci ograniczonego w czasie, prawa pierwszeństwa opublikowania pracy dyplomowej - należą do tych studentów. Natomiast w odniesieniu do osobistych praw autorskich ${ }^{11}$, prawa te zawsze i w pełnym zakresie będą należały do studenta, jeżeli u.p.a.p.p. nie stanowi inaczej. Ogólne przepisy ustawy o prawie autorskim i prawach pokrewnych będą miały także zastosowanie w odniesieniu do rozpraw doktorskich, czy też prac przygotowywanych przez uczestników studiów podyplomowych, bądź innych form kształcenia. We wszystkich tych przypadkach całość zarówno majątkowych, jak i osobistych praw autorskich przysługiwać będzie twórcom, bez jakiegokolwiek prawa lub uprzywilejowania uczelni.

Przechodząc do kwestii związanych z prawami autorskim do utworów, które nie są wynikami badań naukowych „będącymi wynalazkiem, wzorem użytkowym, wzorem przemysłowym lub topografią układu scalonego, wyhodowaną albo odkrytą i wyprowadzoną odmianą rośliny, bądź pracą rozwojową" 12 , stworzonych przez pracowników uczelni publicznej należy przyjąć zgodnie z art. 86 i p.s.w., że są one uregulowane w ustawie o prawie autorskim i prawach pokrewnych i w konsekwencji należy do nich stosować przepisy tej ustawy. Przy takim stanie faktycznym w pierwszej kolejności należy ustalić, czy utwór został stworzony w wyniku wykonywania obowiązków ze stosunku pracy. Jeśli nie powstał on w wyniku wykonywania obowiązków ze stosunku pracy, zastosowanie będą miały przepisy ogólne ustawy o prawe autorskim i prawach pokrew$n y c h$, a w konsekwencji wszelkie majątkowe oraz osobiste prawa autorskie do takiego utworu będą w pełnym zakresie przysługiwały twórcy - pracownikowi, o ile nie jest on związany czy to z pracodawca, czy też $\mathrm{z}$ osobami trzecimi umowami regulującymi te kwestie w sposób odręb$n y^{13}$. W odniesieniu natomiast do utworu, który powstał w wyniku wyko-

11 Zob. Art. 16 u.p.a.p.p.

12 Zob. Art. 86d p.s.w.

13 Zob. B. Howorka, Prawa pracownika szkoty wyżej, „Forum Akademickie” 2009, nr 3, http://forumakad.pl/archiwum/2009/03/21_prawa_autorskie_pracownika_szkoly_wyzszej.html, 19.03.2016. 
nywania obowiązków ze stosunku pracy, w pierwszej kolejności należy ustalić, czy prawa do tak powstałego przedmiotu prawa autorskiego nie zostały uregulowane odmiennie w umowie o pracę lub innej umowie (np. umowie o przyznanie dofinansowania na realizację określonego projektu lub grantu), która jest ściśle związana z realizacją obowiązków wynikających ze stosunku pracy ${ }^{14}$. W przypadku odrębnej regulacji, w pierwszej kolejności to ona będzie miała zastosowanie, a jedynie w zakresie w niej nieuregulowanym zastosowanie znajda przepisy u.p.a.p.p. Natomiast w sytuacji, gdy kwestie dotyczące utworu stworzonego w związku z wykonywaniem obowiązków pracowniczych nie zostały uregulowane odmiennie w umowie o pracę lub innej umowie, zastosowanie znajdą przepisy ustawy o prawie autorskim i prawach pokrewnych.

W kwestii utworów powstałych w wyniku wykonywania obowiązków pracowniczych, w odniesieniu do nauczycieli akademickich, pod uwagę należy brać dwa przepisy u.p.a.p.p. Po pierwsze, należy zwrócić uwagę na przepis art. 14 ust. 1 tejże ustawy, który jest przepisem szczególnym, dotyczącym utworów naukowych stworzonych w wyniku wykonywania obowiązków ze stosunku pracy w instytucji naukowej (a taką z pewnością jest publiczna uczelnia wyższa). Zgodnie z przywołanym przepisem, „Jeżeli w umowie o pracę nie postanowiono inaczej, instytucji naukowej przysługuje pierwszeństwo opublikowania utworu naukowego pracownika, który stworzył ten utwór w wyniku wykonywania obowiązków ze stosunku pracy"15. Prawo pierwszeństwa opublikowania utworu naukowego przysługuje uczelni przez okres sześciu miesięcy liczony od daty dostarczenia utworu. Jeżeli w tym czasie uczelnia nie zawarła $\mathrm{z}$ autorem umowy o wydanie utworu, albo jeżeli w okresie dwóch lat od daty przyjęcia utwór taki (w stosunku do którego podpisano z twórcą umowę o wydanie) nie został opublikowany, wówczas prawo pierwszeństwa wygasa. Pamiętać należy także, że w przypadku korzystania przez uczelnię z prawa pierwszeństwa, twórcy przysługuje wynagrodzenie, o czym wprost stanowi przepis art. 14 ust. 1 u.p.a.p.p. Bezterminowo i bez odrębnego wynagrodzenia uczelnia może jednak korzystać z materiału naukowego zawartego w utworze naukowym pracownika, jak również udostępniać ten utwór osobom trzecim, jeżeli wynika to z uzgodnionego przeznaczenia utworu ${ }^{16}$. Powyższe uregulowania prowadzą do wniosku, że w odniesieniu do utworów naukowych majątkowe prawa autorskie, jak i osobi-

\footnotetext{
14 Por. R. Golat, Prawo autorskie i prawa pokrewne, Warszawa 2013, s. 118-124.

15 Art. 14 ust. 1 u.p.a.p.p.

16 Zob. art. 14 ust. 2 u.p.a.p.p.
} 
ste przysługują autorowi, a więc pracownikowi, z zastrzeżeniem jedynie prawa pierwszeństwa publikacji, przy uwzględnieniu terminów obowiązywania tego prawa ${ }^{17}$. Jest to unormowanie zgoła odmienne od ogólnej zasady wyrażonej w art. 12 ust. 1 u.p.a.p.p., który stanowi, że majątkowe prawa autorskie do utworu powstałego w wyniku wykonywania obowiązków ze stosunku pracy, z chwilą przyjęcia utworu, w granicach wynikających z celu umowy o pracę i zgodnego zamiaru stron, nabywa pracodawca $^{18}$. Z chwilą przyjęcia utworu pracodawca nabywa także własność przedmiotu, na którym utwór utrwalono ${ }^{19}$. Z tytułu stworzenia utworu pracowniczego i przejścia określonego zakresu majątkowych praw autorskich do tego utworu na pracodawcę, pracownikowi nie przysługuje żadne dodatkowe wynagrodzenie ${ }^{20}$. Bez znaczenia dla skuteczności przejścia majątkowych praw autorskich na pracodawcę jest także fakt wypłacenia lub nie wynagrodzenia za pracę ${ }^{21}$.

Choć pracodawca nabywa majątkowe prawa autorskie do utworu stworzonego przez pracownika $\mathrm{w}$ ramach jego obowiązków pracowniczych z chwilą przyjęcia utworu, to nabycie to nie ma charakteru bezterminowego. Pracodawca ma określony termin na przystapienie do rozpowszechniania utworu. Termin ten może zostać określony przez strony $\mathrm{w}$ umowie o pracę dowolnie, a w braku jego określenia zastosowanie znajdzie przepis art. 12 ust. 2 u.p.a.p.p., zgodnie z którym pracodawca ma dwa lata na przystapienie do rozpowszechniania utworu. W przypadku, gdy tego nie zrobi w określonym czasie, wówczas pracownik może, w formie pisemnej, wyznaczyć pracodawcy dodatkowy, odpowiedni termin na rozpowszechnienie. Bezskuteczny upływ tego dodatkowego terminu ma ten skutek, że wszelkie prawa do utworu pracowniczego, które pracodawca nabył wraz z przyjęciem utworu, oraz prawo własności przedmiotu, na którym utwór utrwalono, wracają do twórcy, z mocy prawa. Powyższa zasada ogólna, wyrażona w art. 12 u.p.a.p.p. nie ma jednak zastosowania do szczególnych utworów, jakimi są programy komputerowe ${ }^{22}$. Po

17 Prawo autorskie i prawa pokrewne. Komentarz Lex, op. cit., s. 204-207.

18 Zob. Prawo autorskie i prawa pokrewne. Zarys wykładu (stan prawny na 30 września 2006 r.), red. M. Późniak-Niedzielska, Bydgoszcz 2006, s. 37-39.

19 Zob. art. 12 ust. 3 u.p.a.p.p.

${ }^{20}$ Wynagrodzenie $\mathrm{z}$ tego tytułu jest ujęte $\mathrm{w}$ wynagrodzeniu za pracę.

${ }^{21}$ Zob. Prawo autorskie i prawa pokrewne. Komentarz Lex, red. D. Flisak, Warszawa 2015.

${ }^{22}$ Majątkowe prawa autorskie do programu komputerowego stworzonego przez pracownika w wyniku wykonywania obowiązków ze stosunku pracy przysługują pracodawcy, o ile umowa nie stanowi inaczej - art. 74 ust. 3 u.p.a.p.p. Unormowanie to 
pierwsze, majątkowe prawa autorskie do takiego utworu pracowniczego stają się prawami przysługującymi pracodawcy już w chwili ich powstania - w odniesieniu do programów komputerowych, ustawodawca nie przewidział „przyjęcia utworu”. Nabycie majątkowych praw autorskich w tym przypadku przez pracodawcę ma charakter nabycia pierwotnego (w odróżnieniu od nabycia majątkowych praw autorskich do innych utworów pracowniczych, które ma charakter nabycia wtórnego, albowiem pierwotnie prawa te nabywa autor, który przenosi je na pracodawcę w momencie przyjęcia utworu przez tego drugiego). W dalszej kolejności należy zwrócić uwagę na konsekwencje takiego nabycia praw, które są wielorakie, a najważniejsze $\mathrm{z}$ nich to choćby fakt, że pracodawca uzyskuje całość majątkowych praw autorskich do programu komputerowego, na wszystkich polach eksploatacji, jak również prawo do rozporządzania nim, czy prawo do wynagrodzenia za korzystanie z tego programu, a nie jak to ma miejsce w odniesieniu do innych utworów pracowniczych, do których zastosowanie będzie miał art. 12 u.p.a.p.p., jedynie w granicach wynikających z celu umowy o pracę i zgodnego zamiaru stron ${ }^{23}$. Kolejną konsekwencją pierwotnego nabycia majątkowych praw autorskich przez pracodawcę jest brak możliwości powrotu tych praw do ich twórcy (na zasadach takich, jak to przewidziano w art. 12 ust. 2 u.p.a.p.p.), ponieważ nigdy mu nie przysługiwały.

\section{Prawo własności przemysłowej}

Do końca września 2014 r. kwestie związane z prawami własności przemysłowej powstałej w uczelniach, $\mathrm{w}$ tym $\mathrm{w}$ uczelniach publicznych, były regulowane przepisami ustawy z dnia 30 czerwca 2000 r. Prawo własności przemystowej ${ }^{24}$. Na mocy art. 86d, wprowadzonego do ustawy Prawo o szkolnictwie wyższym z dniem 1 października 2014 roku, w sposób odrębny zostały uregulowane prawa własności przemysłowej do wyników badań naukowych będących wynalazkiem, wzorem użytko-

zasadniczo różni się od omówionego wcześniej art. 12 u.p.a.p.p. J. Barta, R. Markiewicz, Główne problemy prawa komputerowego, Warszawa 1993, s. 116; A. Nowicka, Prawnoautorska i patentowa ochrona programów komputerowych, Warszawa 1995, s. 14.

23 Por. J. Barta, R. Markiewicz, Programy komputerowe, „Rzeczpospolita” z 11.10.1994 r., nr 237, s. 16.

24 Dz. U. 2013, poz. 1410 j.t. ze zm. 
wym, wzorem przemysłowym lub topografią układu scalonego, wyhodowaną albo odkrytą i wyprowadzoną odmianą rośliny oraz do wyników prac rozwojowych powstałych w ramach wykonywania przez pracownika uczelni publicznej obowiązków ze stosunku pracy oraz do know-how związanego z tymi wynikami.

W pierwszej kolejności należy wskazać, że nową regulacją zostały objęte wyłącznie uczelnie publiczne. Przepisy nowelizacji z 2014 roku w zakresie wskazanych powyżej badań naukowych lub prac rozwojowych nie dotyczą uczelni niepublicznych, do których nadal zastosowanie będą miały przepisy prawa własności przemysłowej. W dalszej kolejności należy zwrócić uwagą na fakt, że ustawodawca pominął całkowicie zakresem swojej regulacji studentów i doktorantów uczelni publicznej biorących udział w badaniach naukowych lub pracach rozwojowych w zespołach badawczych. W stosunku do tych osób fizycznych zastosowanie będą miały przepisy prawa własności przemysłowej, więc bardzo istotnego znaczenia nabierze prawidłowe uregulowanie kwestii dotyczących powstałych w czasie takich badań czy prac praw własności intelektualnej w odrębnych umowach podpisywanych z nimi.

Pracownik uczelni publicznej powinien powiadomić uczelnię o wynikach badań naukowych lub prac rozwojowych oraz o know-how związanym z nimi. Ustawodawca w żaden sposób nie uregulował kwestii przekazywania pracodawcy takich informacji, a jedynie poprzez art. 86c ust. 2 pkt 2 p.s.w. nałożył na uczelnię publiczną obowiązek określenia ,zasad i trybu przekazywania uczelni publicznej przez pracownika, studenta lub doktoranta tej uczelni informacji o wynikach badań naukowych lub prac rozwojowych oraz o know-how związanym z tymi wynikami $[\ldots]$ " w regulaminie zarządzania prawami autorskimi i prawami pokrewnymi oraz prawami własności przemysłowej oraz zasad komercjalizacji.

Wprowadzenie w obowiązującym w uczelni publicznej regulaminie zarządzania prawami autorskimi i prawami pokrewnymi oraz prawami własności przemysłowej stosownych zapisów dotyczących trybu i zasad zgłaszania wyników badań naukowych lub prac rozwojowych jest niezmiernie istotne dla prawidłowego ustalenia początku biegu terminu do podjęcia przez uczelnię publiczną stosownych decyzji. W terminie trzech miesięcy od dnia otrzymania od pracownika informacji o wynikach badań naukowych lub prac rozwojowych oraz o know-how związanym $\mathrm{z}$ tymi wynikami, uczelnia jest zobowiązana podjąć decyzję w sprawie ich komercjalizacji - art. 86e ust. 1 p.s.w. 
W przypadku, w którym uczelnia podejmie decyzję o niekomercjalizacji wyników badań naukowych lub prac rozwojowych oraz know-how związanego z tymi wynikami, o których została poinformowana przez pracownika, albo w wyznaczonym trzymiesięcznym terminie nie podejmie żadnej decyzji, jest zobowiązana do złożenia pracownikowi oferty zawarcia bezwarunkowej i odpłatnej umowy o przeniesienie praw do tych wyników. Ustawodawca określił jednocześnie maksymalną wysokość wynagrodzenia przysługującego uczelni publicznej z tytułu przeniesienia tych praw, wskazując że nie może to być kwota wyższa niż $10 \%$ minimalnego wynagrodzenia za pracę obowiązującego $\mathrm{w}$ dacie zawarcia pisemnej (pod rygorem nieważności) umowy o przeniesienie praw do tych wyników - art. 86e ust. 2 p.s.w. Pracownik może ofertę uczelni przyjąć, wówczas dochodzi do podpisania umowy przenoszącej na niego prawa do zgłoszonych przez niego wyników badań naukowych lub prac rozwojowych oraz know-how związanego z tymi wynikami.

W sytuacji, w której pracownik przyjął ofertę uczelni publicznej i dokonał komercjalizacji nabytych w ten sposób wyników badań naukowych lub prac rozwojowych oraz know-how związanego z tymi wynikami, wówczas ,uczelni publicznej przysługuje 25\% wartości środków uzyskanych przez pracownika z komercjalizacji, obniżonych o nie więcej niż 25\% kosztów bezpośrednio związanych z tą komercjalizacją, które zostały poniesione przez pracownika" 25 . Pracownik może także nie przyjąć oferty złożonej przez uczelnię publiczna, w takiej sytuacji prawa do wyników badań naukowych lub prac rozwojowych oraz know-how związanego z tymi wynikami pozostają w uczelni publicznej.

Podejmując decyzję o komercjalizacji wyników badań naukowych lub prac rozwojowych oraz know-how związanego z tymi wynikami, uczelnia musi mieć na uwadze, że pracownikowi będzie przysługiwało „nie mniej niż: 1) 50\% wartości środków uzyskanych przez uczelnię z komercjalizacji bezpośredniej, obniżonych o nie więcej niż $25 \%$ kosztów bezpośrednio związanych z tą komercjalizacją, które zostały poniesione przez uczelnię lub spółkę celową; 2) 50\% wartości środków uzyskanych przez spółkę celową w następstwie danej komercjalizacji pośredniej, obniżonych o nie więcej niż $25 \%$ kosztów bezpośrednio związanych z tą komercjalizacją, które zostały poniesione przez uczelnię lub spółkę celową"26.

\footnotetext{
25 Zob. Art. 86 f ust. 2 p.s.w.

${ }_{26}$ Zob. Art. 86 f ust. 1 p.s.w.
} 
Podejmowanie przez uczelnię publiczną decyzji o komercjalizacji lub niekomercjalizacji wyników badań naukowych lub prac rozwojowych oraz know-how związanego z tymi wynikami, jak również konsekwencje związane z podjęciem określonej decyzji, nie dotyczą sytuacji, ,gdy badania naukowe lub prace rozwojowe były prowadzone na podstawie umowy ze stroną finansującą lub współfinansującą te badania lub prace, przewidującej zobowiązanie do przeniesienia praw do wyników badań naukowych lub prac rozwojowych na rzecz tej strony lub na rzecz innego podmiotu niż strona umowy (badania lub prace zlecone) lub z wykorzystaniem środków finansowych, których zasady przyznawania lub wykorzystywania określają odmienny niż w ustawie sposób dysponowania wynikami badań naukowych lub prac rozwojowych oraz know-how związanym z tymi wynikami ${ }^{27 ”}$. Co więcej, ,po otrzymaniu od pracownika informacji o wynikach badań naukowych lub prac rozwojowych oraz o know-how związanym z tymi wynikami, [...], uczelnia publiczna oraz pracownik mogą, w sposób odmienny niż stanowi ustawa, określić w drodze umowy prawa do tych wyników lub sposób i tryb komercjalizacji tych wyników"28. W zakresie nieuregulowanym przepisami szczególnymi ustawy Prawo o szkolnictwie wyższym, do praw własności przemysłowej zastosowanie będą miały przepisy ustawy z dnia 30 czerwca 2000 r. Prawo własności przemystowej.

\section{Regulamin własności intelektualnej UAM}

Na podstawie art. 86c ust. 1 pkt 1 ustawy Prawo o szkolnictwie wyższym, Senat Uniwersytetu im. Adama Mickiewicza w Poznaniu uchwała nr 202/2015 z dnia 23 marca 2015 r. wprowadził Regulamin zarzadzania prawami autorskimi i prawami pokrewnymi oraz prawami wtasności przemystowej oraz zasad komercjalizacji w Uniwersytecie im. Adama Mickiewicza w Poznaniu ${ }^{29}$ (zwany dalej Regulaminem). W pierwszej części dokument ten przede wszystkim definiuje pojęcia, którymi posługuje

27 Zob. Art. 86e ust. 4 p.s.w.

28 Zob. Art. 86h p.s.w.

${ }^{29}$ Regulamin zarzadzania prawami autorskimi i prawami pokrewnymi oraz prawami własności przemysłowej oraz zasad komercjalizacji w Uniwersytecie im. Adama Mickiewicza w Poznaniu, https://pracownicy.amu.edu.pl/_data/assets/pdf_ file/0004/269041/Za_uchwaa_202_REGULAMIN.pdf, 19.03.2016. 
się w swej dalszej treści oraz określa zakres podmiotowy i przedmiotowy regulacji.

Zakresem podmiotowym Regulaminu objęci zostali pracownicy uczelni, doktoranci, studenci oraz osoby trzecie uczestniczące w projektach badawczych lub pracach rozwojowych realizowanych w Uniwersytecie. Z uwagi na fakt, że studentów, a także większość doktorantów wiąże $\mathrm{z}$ uczelnią jedynie stosunek administracyjno-prawny związany z odbywaniem studiów wyższych, czy też uczestniczeniem w studiach trzeciego stopnia - studiach doktoranckich, są oni związani postanowieniami Regulaminu „o ile wiąże ich z uniwersytetem odrębna umowa, która przewiduje stosowanie $\mathrm{w}$ stosunkach pomiędzy stronami postanowień regulaminu lub złożyli oświadczenia o przyjęciu do wiadomości obowiązywania regulaminu i zobowiązali się do jego przestrzegania"30. Także krąg osób trzecich związanych postanowieniami Regulaminu został zawężony jedynie do osób „uczestniczących w projektach, o ile wiąże je $\mathrm{z}$ uniwersytetem odrębna umowa, która przewiduje stosowanie w stosunkach pomiędzy stronami postanowień regulaminu lub złożyły oświadczenia o przyjęciu do wiadomości obowiązywania regulaminu i zobowiązały się do jego przestrzegania"31. Mając na uwadze fakt, że postanowienia § 2 Regulaminu odnoszą się przede wszystkim do osób fizycznych, na mocy przepisu $\S 3$ tego dokumentu wskazano, że „Postanowienia regulaminu mają również zastosowanie w relacjach pomiędzy uniwersytetem a innymi podmiotami, z którymi realizowane są projekty współfinansowane lub projekty komercyjne, lub inne działania związane z istniejącymi lub mogącymi powstać dobrami intelektualnymi, o ile wiąże je z uniwersytetem odrębna umowa, która przewiduje stosowanie w stosunkach pomiędzy stronami postanowień regulaminu"32. Zakresem przedmiotowym Regulaminu objęto dobra intelektualne, „W szczególności, powstałe w związku z wykonywaniem obowiązków ze stosunku pracy, uzyskane w trakcie realizacji projektów, uzyskane w trakcie prac nad pracą dyplomową albo rozprawą doktorską, uzyskane w trakcie stypendiów lub urlopów naukowych, do których uniwersytet nabył prawa w wyniku innych zdarzeń prawnych" ${ }^{33}$.

Dalsze postanowienia Regulaminu regulują w szczególności wszystkie kwestie wskazane w art. 86c ust. 1 i 2 p.s.w., ale także starają się

\footnotetext{
${ }^{30}$ Zob. § 2 pkt 2) i 3) Regulaminu.

31 Zob. § 2 pkt 4) Regulaminu.

32 Zob. \& 3 Regulaminu.

33 Zob. § 5 Regulaminu.
} 
wychodzić naprzeciw oczekiwaniom między innymi pracowników naukowych oraz naukowo-dydaktycznych. Szczególnym tego przykładem są jego zapisy odnoszące się do prawa pierwszeństwa publikacji utworu naukowego, zgodnie z którymi, „Kierując się zasadą swobody badań naukowych i dążąc do zapewnienia pracownikom możliwości publikowania utworów naukowych w najbardziej renomowanych publikatorach, uniwersytet nie będzie wykonywał prawa pierwszeństwa, o którym mowa w ust. 1, z wyłączeniem następujących przypadków: 1) publikacja utworu naukowego naruszyłaby zobowiązania uniwersytetu wynikające z umów lub decyzji dotyczących realizacji projektów komercyjnych, projektów współfinansowanych lub bezwzględnie obowiązujących przepisów prawa; 2) publikacja ujawniałaby rezultaty, a ujawnienie takie pozbawiłoby uniwersytet lub osobę trzecią możliwości podjęcia czynności postępowania ochronnego w stosunku do tych rezultatów lub możliwości ich gospodarczego wykorzystania"34.

W momencie pisania niniejszego artykułu naukowego mija rok od uchwalenia przez Senat UAM Regulaminu zarzadzania prawami autorskimi i prawami pokrewnymi oraz prawami własności przemystowej oraz zasad komercjalizacji w Uniwersytecie im. Adama Mickiewicza w Poznaniu. Chcąc przekonać się na ile społeczność akademicka zdaje sobie sprawę $\mathrm{z}$ faktu istnienia tegoż dokumentu autorki niniejszej publikacji skorzystały z metody behawioralnej celem uzyskania odpowiedzi od respondentów na zapytanie: „Czy znasz wewnętrzny akt prawny, który reguluje zagadnienia zakresu własności intelektualnej na UAM?”. Wyniki są zatrważające. Na 100 zapytanych studentów, nikt nie wiedział, że takowy Regulamin istnieje. $Z$ kolei robiąc rozeznanie wśród pracowników dydaktyczno-naukowych i administracyjnych tej uczelni (50 osób zapytano o tę kwestię) można wywnioskować, że większość z nich zdaje sobie sprawę $z$ istnienia tego dokumentu, jednak mało kto sięgnął do jego treści (tylko 4 respondentów). Pozwala to na wysunięcie postulatu sprowadzającego się do stworzenia oraz wdrożenia kampanii informacyjnej na Uniwersytecie im. Adama Mickiewicza w zakresie własności intelektualnej. Poza tym należałoby przeprowadzić, w oparciu o zapisy tegoż dokumentu, szereg szkoleń zarówno z pracownikami, studentami, jak i doktorantami, celem zwiększenia wiedzy z tego obszaru. Bowiem Regulamin z zakresu własności intelektualnej wydaje się być nieodzownym elementem kształtowania porządku prawnego na każdej uczelni wyższej.

\footnotetext{
${ }^{34}$ Zob. § 10 ust. 4 Regulaminu.
} 
Ustala bowiem bardzo ważną sferę działalności ludzkiej o twórczym charakterze $^{35}$. Pozwala na doprecyzowanie tego, co do tej pory wielu podmiotom funkcjonującym w jej obrębie nie było uświadamiane. Reguluje kwestie dysponowania prawami do utworu zarówno przez twórców, jak i ich pracodawcę.

\section{Bibliografia}

Barta J., Markiewicz R. (1993), Główne problemy prawa komputerowego, Warszawa.

Barta J., Markiewicz R. (1994), Programy komputerowe, „Rzeczpospolita” z 11.10, nr 237.

Golat R. (2013), Prawo autorskie i prawa pokrewne, Warszawa.

Howorka B. (2009), Prawa pracownika szkoły wyżej, „Forum Akademickie”, nr 3, http://forumakad.pl/archiwum/2009/03/21_prawa_autorskie_pracownika_ szkoly_wyzszej.html, 19.03.2016.

Narożna D. (2012), Własność intelektualna w kontekście funkcjonowania uczelni wyższej w Polsce (część 1), „Środkowoeuropejskie Studia Polityczne”, nr 4.

Nowicka A. (1995), Prawnoautorska i patentowa ochrona programów komputerowych, Warszawa.

Prawo autorskie i prawa pokrewne. Komentarz Lex (2015), red. D. Flisak, Warszawa.

Prawo autorskie i prawa pokrewne. Zarys wykladu (stan prawny na 30 września 2006 r.) (2006), red. M. Późniak-Niedzielska, Bydgoszcz.

Regulamin zarzqdzania prawami autorskimi i prawami pokrewnymi oraz prawami wtasności przemystowej oraz zasad komercjalizacji w Uniwersytecie im. Adama Mickiewicza w Poznaniu, https://pracownicy.amu.edu.pl/_data/assets/ pdf_file/0004/269041/Za_uchwaa_202_REGULAMIN.pdf.

Szewc A. (1995), Prawo autorskie w szkole wyższej (część 1), „Gazeta Uniwersytecka UŚ", nr 5, http://gazeta.us.edu.pl/node/194381, 19.03.2016.

Ustawa z dnia 4 lutego 1994 r. o prawie autorskim i prawach pokrewnych, Dz. U. 2006, Nr 90, poz. 631 j.t. ze zm.

Ustawa z dnia 30 czerwca 2000 r. Prawo własności przemysłowej, Dz. U. 2013, poz. 1410 j.t. ze zm.

Ustawa z dnia 27 lipca 2005 r. Prawo o szkolnictwie wyższym, Dz. U. 2012, poz. 572, j.t. ze zm.

Ustawa z dnia 18 marca 2011 r. o zmianie ustawy - Prawo o szkolnictwie wyższym, ustawy o stopniach naukowych i tytule naukowym oraz o stopniach $i$ tytule w zakresie sztuki oraz o zmianie niektórych innych ustaw, Dz. U. 2011, Nr 84, poz. $455 \mathrm{ze}$ zm.

${ }^{35}$ A. Szewc, Prawo autorskie w szkole wyższej (część 1), „Gazeta Uniwersytecka UŚ” 1995, nr 5, http://gazeta.us.edu.pl/node/194381, 19.03.2016. 
Ustawa z dnia 11 lipca 2014 r. o zmianie ustawy - Prawo o szkolnictwie wyższym oraz niektórych innych ustaw, Dz. U. 2014, poz. 1198, ze zm.

Wyrok Sądu Ochrony Konkurencji i Konsumentów z dnia 6 kwietnia 2006 r. wydany w sprawie o sygn. akt XVII AmC 48/05, niepubl.

Intellectual property in a public university (part 2). The case of Adam Mickiewicz University in Poznań

\section{Summary}

Intellectual property and its protection is a current and evolving matter. A lot has been written on this topic and more considerations will follow, both on account of changing legislation and numerous details that deserve attention and reflection. The authors of this paper focus on the issue of intellectual property in a public university. This subject is becoming increasingly topical, as there are more and more encouragements and incentives aiming to enhance the cooperation between academia and industry, which is inevitably related to the issue of rights discussed in this paper.

Key words: intellectual property protection, work, subjects of copyright 
